\title{
EXPOSING THE DARK SIDE OF STATE FINANCE WATCH
}

\author{
Jamaluddin $^{1,2 \star}$, Sukoharsono Eko Ganis ${ }^{3}$, Irianto Gugus ${ }^{3}$, Rosidi ${ }^{3}$ \\ ${ }^{1}$ Doctoral Program of Accounting Science, Faculty of Economics and Business, \\ University of Brawijaya, Malang, Indonesia \\ ${ }^{2}$ Faculty of Economics and Business, University of Mulawarman, Samarinda, Indonesia \\ ${ }^{3}$ Faculty of Economics and Business, University of Brawijaya, Malang, Indonesia \\ *E-mail: jammmal68@gmail.com
}

\begin{abstract}
The aim of this paper is to expose the problems of state finance watch, which can be found in monitoring agencies that include the House of Representatives, the Regional Representative Council, the Regional House of Representatives, the Audit Board of Indonesia (BPK), Finance and Development Supervisory Agency (BPKP), and the Inspectorate. The multiple problems lead to the lack of synergy among these agencies in conducting their function to monitor the state finance to the degree that corruptions still take place in all levels in the government from the national level to the regional government, in the legislative, executive, as well as the judicative branches. This research is qualitative literature study approach. The results of the study indicate that the state financial supervisor has not functioned effectively. This is indicated by the degree of state finance loss that is considerably high gives the impression that the corruption eradication is stalled. In addition, the current watch is unable to ensure good governance. This indicates that supervisory institutions must improve their performance in order to be able to prevent state finances loss.
\end{abstract}

\section{KEY WORDS}

Finance monitoring, House of Representatives (DPR), Regional Representative Council (DPD), Regional House of Representatives (DPRD), Audit Board of Indonesia (BPK), Finance and Development Supervisory Agency (BPKP), inspectorate, corruption.

Corruption and monitoring are two inseparable matters. With good monitoring, corruption can be contained, while with poor monitoring, corruption will increase. Such as the case although the factors that cause corruption are not only limited to monitoring; other factors may contribute to corruption. Nevertheless, the occurrence of corruption can indicate the performance of the monitoring function.

Government's efforts to minimize corruption have been manifested in various government programs, such as among others the publication of the National Strategy for the Prevention and Eradication of Corruption (Stranas PPK), bureaucratic reforms, and good governance that is expected to create officials that are professional and have high integrity. In addition, the government has issued Law Number 28 Year 1999 on State Administration that is Clean and Free from Corruption, Collusion, and Nepotism. This law is expected to result in clean, transparent, and accountable governance in all aspects of governance. The anti-corruption commitment must be maintained by both state apparatus and the people so that the national goal of realizing a just and prosperous society can be achieved. (Andrianto and Irianto, 2008, hlm. 162) affirm that this matter becomes an integral part that must be fulfilled to realize prosperity for all people.

Realizing a clean, transparent, and accountable governance that is free from corruption, particularly within the affairs of regional governments, is the task of the institution of the Inspectorate, as regulated in Government Regulation No. 41 Year 2007 (Zawilska and Albury, 2015) on the Organization of Regional Officials. However, there also other institutions that monitor state administration, i.e. the House of Representatives (DPR), the Regional House of Representatives (DPRD), State Financial Accountability Institution (BAKN), the Audit Board of Indonesia (BPK), and Non-Governmental Organizations (NGOs), as well as the people; the multitude of these monitoring agencies should result in a state administration 
that is clean and free from corruption. However, corruption eradication has not led to satisfactory results.

The monitoring of state administration is conducted in levels from the central government to the regional governments, both internally and externally. Internally, the monitoring duties are mandated to Government's Internal Auditor (APIP), which is present on each level of government organizations. In addition, there is also the Finance and Development Supervisory Agency (BPKP), which is an internal auditor under an executive agency (Asosiasi Auditor Intern Pemerintah Indonesia (AAIPI)) led by the president. There are also Inspectorate-Generals under ministries and the (Primary) Inspectorate under the Non-Departmental Government Agencies (LPND), the Province-Level Regional Inspectorate (Itwilprop) under the regional government of the province, and the Regency/Municipality Regional Inspectorate under the regional government of the regency/municipality-level government auditor. Externally, the institution that monitors the government is the Audit Board of Indonesia. The Audit Board of Indonesia is the only external government monitor institution for the finance sector given the mandate through Law Number 15 Year 2004 on the Audit of Management and Responsibility of State Finances.

In addition to the monitoring institutions, there are three institutions that may conduct investigations in cases of misappropriations of state funds; they are the Corruption Eradication Commission (KPK), Office of the Attorney General of Indonesia (KEJARI), and Indonesian National Police (POLRI). Also, there are non-governmental organizations that focus on the implementation of clean governance that is free from corruption, collusion, and nepotism, such as the Indonesian Corruption Watch (ICW), Center for Anti-Corruption Studies (PUKAT) of UGM, Indonesian Forum for Budget Transparency (FITRA), and other institutions, including members of society. Financial monitoring institutions are present in the judicial, legislative, and executive branches. In the executive branch, finance monitoring institutions have been established ranging from the level of central government all the way down to the level of regional governments. The Internal Monitor Unit (SPI)has even been established in each government office.

The multitude of state financial monitoring institutions should result in the management of state finances that is more effective, efficient, economical, and free from corruption and various other negative stigmas. In reality, however, the condition is different, as expressed by President Joko Widodo while opening the National Coordination Meeting for the Finance and Development Supervision Body on Wednesday, May 13, 2015. President Joko Widodo expressed his disappointment over the monitoring performance of state finances, which still fell short of expectations. This shows that internal monitoring apparatus is still not able to provide a guarantee of good governance in preventing corruption (Wibowo, 2015). Similarly, as expressed by (Wiyono, 2014) and (Kumorotomo, 2014), the standards for successful monitoring are the ability to prevent embezzlement and corruption, and to minimize corruption, collusion, and nepotism that is indicated by the embezzlement of the everdecreasing state finance.

Studies have been conducted in the field of monitoring by earlier researchers. One of them was conducted by (Sujana, 2012) on the Inspectorate offices of Badung and Buleleng Regencies, where it was discovered that increasing the performance of regional government's internal auditors can be achieved by increasing competence, motivation, and appropriateness of roles, and strengthening organizational commitment. Another study, conducted by Wawo (2012) on internal and external monitoring on the performance of regional apparatus task force (SKPD) in the Province of Southeast Sulawesi, showed that professional external monitoring will affect financial reporting performance, while internal monitoring does not affect financial reporting performance because of the lack of competence and consistent enforcement of independence, as well as the strength of influence and intervention of superiors.

Ludigdo (2007) stated that an auditor in performing duties is not only oriented to the completion of audit tasks. In aiding the client in resolving the problems, this also becomes happiness in and of itself for the auditor. Tuanakotta (2013) explains that to maintain professionalism, an auditor needs to evaluate the five elements of internal control over the 
auditor: Control Environment, Risk Assessment, Information System, Monitoring Activities, and Monitoring.

A study conducted by Maroun and Atkins (2014) in South Africa on the quality of audit indicates that the enforcement of regulations regarding professional auditing was done in a legalistic manner or that the audit was conducted for show to create the impression of professionalism, and recommendations from the auditor are more symbolic in nature. In line with this, Handajani (2010) explains that public accountability in public sector organizations emphasize more on economic accountability or what can be measured quantitatively, while non-economic or non-quantitative aspects are ignored.

In conducting their monitoring or auditing tasks, the monitoring agency sometimes ignores the dimension of greater public interests for political reasons and puts the reporting process forward while reducing or eliminating social and religious values. In line with this, Duska, Duska, and Ragat (2011) explain that auditors are not only responsible for the financial report of the auditee, but they must also be responsible to the public because an audit report can increase positive response from the public.

The research conducted by Liu and Jin (2012) on the role of government audit in corruption control in China shows that it can be ascertained that the number of misapplications detected in a regional government audit is linked to the corruption in such province. Thus, there needs to be a greater effort to reduce corruption. This proves that regional government audit contributes to reduce corruption. Meanwhile, the research by (Lowensohn, Johnson, Elder, and Davies, 2007) on audit quality indicates that audit companies that specialize on government audits will have a positive influence on the quality of resulting audits.

The various phenomena detailed above encourage the writers to conduct a further study in the field of financial monitoring, particularly to expose the dark side of state finance monitoring. What distinguishes this research from previous research is that this research is qualitative literature study approach. In addition, the object of this research includes all state financial supervisory institutions regulated according to legislation, namely the House of Representatives, the Regional Representative Council, the Regional House of Representatives, the Audit Board of Indonesia, Finance and Development Supervisory Agency, and the Inspectorate. Whereas previous research only discussed the supervisory institution partially.

\section{LITERATURE REVIEW}

State Finance Monitoring. The management of state finance is vital in the efforts to achieve state goals, which are to make the people prosperous, to guarantee people's rights, and to provide services to the people. These goals can be achieved if the management of state finance as a central point of the organization can proceed well and good management of financial administration can make all elements of the organization work better. Because of that, monitoring on the management of state finance is necessary to ensure that the management of finance proceeds according to the appropriate practices pertinent to the applicable regulations of law. In addition, monitoring is also a consequence of a democracy to ensure that the government is maintaining its authority in compliance with the regulations of law.

"Monitoring" is a word with various meanings, depending on its context and the situation of parties being monitored. Examples are "This property and building are currently under bank monitoring" or "So-and-so is under police monitoring". As such, the word "monitoring" creates psychological effects, particularly for the environment of the parties being Monitoring. "Monitoring" has a wide, general understanding, while audit is a part of monitoring.

Aside from the meaning of the word, what often becomes a problem is not only the implications of monitoring, but also many kinds of monitoring or things that are similar to monitoring such as review, evaluation, examination, audit, supervision, and consultation. These terms are similar but are not the same. Yet the party being "monitored" is 
psychologically affected in much the same way. To provide a general picture of the "tangled threads" of state financial monitoring, the monitoring as conducted by the state, the relationships of monitoring institutions, and their problems will be explained.

Monitoring is a part of the management function to compare between the results that have been achieved and the targets that have been set, and this becomes and evaluation to find out whether misappropriations have occurred in achieving the targets and to see how resources have been used. Monitoring is needed not because there is a lack of confidence in state officials or simply to find mistakes. Instead, monitoring can lead to an evaluation for future improvements.

Direct monitoring by superiors, or commonly called "built-in monitoring", is considered internal monitoring. The implementation of built-in monitoring can be considered analogous to "angelic monitoring". In the religion of Islam, every person is thought to be accompanied by two angels who record all the activities of the person. However, in built-in monitoring, managers are expected to be able to oversee all the activities of their subordinates so that they may take preventive and/or repressive actions, in order that the planned objectives may be effectively and efficiently achieved according to applicable regulations (Instruksi Presiden Nomor 1, 1989).

Monitoring by Audit Board of Indonesia is an external monitoring that is conducted for the interests of the DPR/DPRD as the holders of the monitoring and budgeting functions (Fahrojih, 2016). Even so, other agencies and the public may also peruse the monitoring reports of the Audit Board of Indonesia according to their interests. Thus, both the Audit Board of Indonesia and the House of Representatives/Regional House of Representatives are external monitoring agents for the government because there is no functional relationship of between the Audit Board of Indonesia and the House of Representatives/Regional House of Representatives; they are related as partners simply because both are higher bodies of the state.

Monitoring on the government may be done in a preventative or detective manner. Preventative monitoring is monitoring that is performed early on, before a program is executed and funds are spent, with the aim that any deviations that might occur can be prevented (Baswir, 2000). Further, (Baswir, 2000) explains that the goals of preventative monitoring are to (1) avoid violations of legal regulations, (2) create a reference so that activities may proceed effectively and efficiently, (3) determine expected goals and targets, and (4) establish responsibility and authority of the institution regarding the duties that must be performed.

Detective monitoring has the purpose of comparing what has happened and what should have happened. As such, detective monitoring is usually performed at the end of an activity. Accountability report documents are examined and evaluated to ensure that the execution of activities and funding proceed according to principles of general monetary policies and applicable regulations.

Conceptually, the Audit Board of Indonesia should perform the financial audit in detail for all budgetary processes including planning, costing, spending, record-keeping, and reporting, as well as accountability, but in reality, what happens is that the Audit Board of Indonesia only conducts audits regarding accountability of state or regional budgets and expenditures (APBN/APBD), in particular budget realization (Direktorat Jenderal Anggaran, 2015). Thus, the possibility of state funds exceeding the early stage of the budgeting process is not detected by the Audit Board of Indonesia, the Finance and Development Supervision Body, and the Inspectorate.

Monitoring Institutions for State Finance. Monitoring institutions for state finance are responsible for overseeing the National Budgets and Expenditures and the Regional Budgets and Expenditures in order to prevent misspending so that the established objectives may be achieved. Some of these institutions are external such as the House of Representatives, Regional Representative Council, Regional House of Representatives, and Audit Board of Indonesia, and there are also internal ones such as the Finance and Development Supervision Body and the Inspectorate. The following is the general description of those monitoring bodies. 
The House of Representatives, Regional Representative Council and Regional House of Representatives. The legislation, budgeting, and monitoring functions are inherent to the House of Representatives. The House of Representatives is of the same rank as the President and Vice-President as well as several state institutions such as the Regional Representative Council, People's Consultative Assembly (MPR), Supreme Court (MA), Constitutional Court (Goddard, Assad, Issa, Malagila, and Mkasiwa) (Goddard dkk.), and the Audit Board of Indonesia. Members of the House of Representatives are representatives of the people, and they are elected once every five years from members of political parties. The term of House of Representatives ends when newly elected representatives take their oath of office (Undang-Undang No 27 tahun 2009).

In the beginning, the House of Representatives was called the Central Indonesia National Committee (KNIP), formed by the first president of Indonesia, Soekarno, on August 29, 1945, with 150 members and it was led by Mr. Kasman Singodimedjo as the Executive Chair of the Committee as well as the Chair of the Central Indonesia National Committee. The Central Indonesia National Committee was what laid the foundations for the formation of the House of Representatives, and thus the date on which the Central Indonesia National Committee was started is also the day the House of Representatives was founded. The Central Indonesia National Committee was adjourned on February 15, 1950, and changed its name to the House of Representatives (Syafruddin, 1991), (Rozi, 2010).

After the end of the Central Indonesia National Committee and before the formation of the House of Representatives following the second election on October 28, 1971, the House of Representatives has experienced many changes, such as the formation of the House of Representatives and Senate of the United Republic of Indonesia, the Temporary House of Representatives (DPRS), the House of Representatives from the first elections, the House of Representatives from the Presidential Decree of 1959, DPR GR (the House of Representatives "Gotong Royong"), DPR GR without the Communist Party of Indonesia (PKI), and the House of Representatives during the New Order. Historically, from the second elections up to the most recent in 2018, the House of Representatives members have been elected from members of political parties.

The House of Representatives is a representative institution for the people and is positioned in the central government as the extension of the People from all over Indonesia. At the provincial and regent/city levels, there are also Regional House of Representatives, which is representatives of the people at the provincial, regent, and city levels, which along with the executive and other government institutions carry out regional governance in accordance with their authorities and responsibilities. In addition to having the functions of legislation and budgeting, the Regional House of Representatives also has a supervisory function (Manan, 2005), (Rozi, 2010).

The three functions of the Regional House of Representatives are carried out in order to represent the people in their regions. The Regional House of Representatives also has the function of overseeing the execution of the Regional Budget to prevent any misspending by considering regional regulations and other regulations, the Regional Budget, decisions by the governor/regent/mayor, and policies established by the regional government (UndangUndang No 22 tahun 2003), (Undang-Undang No 27 tahun 2009), (PP No 25 Tahun 2004).

The monitoring conducted by the Regional House of Representatives is not as technical- and detail-oriented as that of the Audit Board of Indonesia, Finance and Development Supervision Body, and the Inspectorate, but the monitoring is performed through what the Regional House of Representatives does, including hearings, work meetings, discussions with special committees, declaration of views in plenary meetings, and working visits (PP No 25 Tahun 2004). Article 26 letter (i) of Law No. 22 of Year 2003 on the Structure and Position of the People's Consultative Assembly (MPR), House of Representatives, Regional Representative Council, Regional House of Representatives of the Province, and the Regional House of Representatives of the city states that the House of Representatives has the functions of "conducting discussions and following up the report of the audit carried out by the Audit Board of Indonesia" (Undang-Undang No 22 tahun 2003). The same is true for the Regional House of Representatives, where examination reports by 
the Finance Auditor Body becomes a discussion material for the Regional House of Representatives in meetings with the executive bodies.

In Article 23 of the 1945 Constitution, it is stated that the National Budgets and Expenditures is a realization of the management of state finance, which represents the revenue and expense of the state that is established each year by law. This shows that the House of Representatives/Regional House of Representatives has the right to establish monitoring in the field of state finance. To carry out these functions, the House of Representatives or the Regional House of Representatives and the Finance Auditor Body work hand in hand to oversee state finance. The monitoring instituted by the House of Representatives and the Regional House of Representatives are not technical in nature but are directed towards ensuring that what has been established in the State Budget/Regional Budget can be achieved according to the set targets.

In addition to the House of Representatives and the Regional House of Representatives, overseeing the State Budget is also done by the Regional Representative Council. Before 2004, the Regional Representative Council was called the Provincial Delegates. The Regional Representative Council is meant to accommodate regional interests within national interests to preserve national integration. Members of the Regional Representative Council are provincial representatives elected through a non-party election, where four people are chosen from each province.

The function of the Regional Representative Council is slightly different from the House of Representatives because the former prioritizes the struggle for regional interests, though in general the two have some commonalities. The Regional Representative Council may also propose laws, conduct discussions on them, and provide considerations on proposed laws, especially if the laws concern regional interests. The Regional Representative Council also oversees the execution of certain laws, including laws related to the State Budget. In addition, in relation to financial monitoring, the Regional Representative Council also receives audit reports from the Finance Auditor Body and gives the results of its actions to the House of Representatives.

Audit Board of Indonesia (BPK). The Audit Board of Indonesia (BPK) was formed on December 28, 1946, one year after the declaration of independence, when the government established the formation of the Finance Auditor Body through Decree Number 11/OEM with temporary positioning at Magelang. The first chief of Audit Board of Indonesia was R. Soenarno. In 1947, Yogyakarta became the national capital, and thus a branch office of the Finance Auditor Body was created in Yogyakarta; later, the Finance Auditor Body Yogyakarta branch office was established as the central office of the Finance Auditor Body in 1948 and the Finance Auditor Body office at Magelang became a branch office. This change was explained in Government Decree Number 6 of Year 1948 on November 6, 1948 (Sekretariat Utama BPK RI, 1972).

Political progress after the Declaration of Independence on 17 August 1945 was not smooth. The Dutch government, the former colonizing country, launched a second military aggression on 19 December 1948. But after urging from the international community, negotiations were held with the Dutch government. The result was that on December 19, 1949, after a deal was struck in the Round Table Conference, the Republic of Indonesia became the United Republic of Indonesia (RIS).

In accordance with the Constitution of the United Republic of Indonesia, which sanctions the establishment of a Financial Supervisory Council, President Soekarno appointed R. Soenarno to be the chief of the Financial Supervisory Council with an office in Bogor. But this Financial Supervisory Council only lasted for less than a year.

On 17 August 1950, on the fifth anniversary of the independence of Indonesia, President Soekarno announced a change in the form of the government from the United Republic of Indonesia to the Republic of Indonesia. After the change to the Republic of Indonesia and based on the Temporary Constitution, the Financial Supervisory Council and the Audit Board of Indonesia were merged on 1 October 1950.

The failure of the Constitutional Assembly to formulate a new constitution to replace the 1950 Temporary Constitution forced President Soekarno to issue the Presidential Decree of 
5 July 1959, which caused the 1945 Constitution to become applicable again. The consequence of the enforcement of the 1945 Constitution was that previously formed financial audit body would be transformed into the Audit Board of Indonesia as regulated in Article $23 \mathrm{E}$ of the 1945 Constitution, which regulates the formation of the Audit Board of Indonesia to conduct audits on the management and responsibility of state finance.

The operational legal foundation used by the Financial Supervisory Institution and the Financial Audit Institution is the legacy laws from the Dutch colonial era up to the issuance of the Government Regulation in Lieu of Law Number 7 of Year 1963 on the Audit Board of Indonesia. The Audit Board of Indonesia is the only institution of financial audit mentioned in the 1945 constitution. As such, the Finance Auditor Body must be independent in conducting duties of audit to other agencies as well as the executive.

As a state institution that carries out the function of auditing finances, the Finance Auditor Body certainly possesses relationship and closeness with the House of Representatives, which also functions to oversee the progress of governance in general. This is evident in that the audit report by the Finance Auditor Body must be provided to the House of Representatives as input for the House of Representatives in evaluating the performance of the executive or other institutions. To strengthen the position of the Audit Board of Indonesia as a state institution that conducts the function of auditing state finances, this is regulated further by Law Number 15 of Year 2004 on the audit of management and responsibility of state finances.

The third amendment to the 1945, in particular Chapter VIIIA, article 23 on the Audit Board of Indonesia, strengthens the position of the Finance Auditor Body as an audit institution that is free and independent. As a consequence of this amendment, the Audit Board of Indonesia becomes required to provide the audit report not only to the House of Representatives but also the Regional Representative Council, Regional House of Representatives at the Province, and the House of Representatives at the Regent or City level. As such, the scope of obligations of the Finance Auditor Body in providing the audit report is greater, which is expected to contribute to the standing of legislative institutions in conducting monitoring.

The Audit Board of Indonesia, as an external institution, conducts post-audits to evaluate the execution of an activity that the government does. The evaluation aspects of the Finance Auditor Body concern with efficiency, effectiveness, and appropriateness to applicable legal regulations. The audit report of the Finance Auditor Body is used by the legislative not only for monitoring of the executive, but also possibly as a reference in drafting the budget of the following year.

Government Internal Monitoring Apparatus (APIP). The government internal monitoring apparatus is composed of the Finance and Development Supervision Body, the Inspectorate General (Itjen), Provincial or Regional Inspectorate/Monitoring Agency (Itwil/Bawasda), City or Regent Inspectorate/Monitoring Agency, and Internal Monitoring Units (SPI) in Regional Task Forces (SKPD), State-Owned Enterprises (BUMN), and Regionally-Owned Enterprises (BUMD), which all perform the same monitoring function. It can thus be said that internal monitoring institutions are those that are present within the government structure and are responsible to the leaders of the organizational unit. To illustrate the structure of the Government Internal Monitoring Apparatus, the Finance and Development Supervision Body is first explained before proceeding to the Inspectorate.

The Finance and Development Supervision Body. The Finance and Development Supervision Body is a non-ministry internal audit institution of the government that has the duty of overseeing finances and development. Although it is an audit institution, the Finance and Development Supervision Body does not solely conduct audits, but also provides consultation, assistance, education, and training related to financial management in accordance with applicable legal regulations.

The Finance and Development Supervision Body was formed before the Declaration of Independence on 17 August 1945, under the name of the Office of State Accountants (DAN), which became the progenitor of the Finance and Development Supervision Body. The Office of State Accountants, which was at the time under the government of the Dutch colony, 
aimed to oversee and to investigate state companies and certain institutions. At the time, the Office of State Accountants was organizationally under the Treasury-General of the Ministry of Finance, which was formed by the Government Decree (Government Besluit) Number 44 on 31 October 1936.

In 1961, the Office of State Accountants transformed its function, becoming a government agency to conduct all accounting work for all state interests, whether in departments, state companies, or other (non-department) government institutions. This change of function of the Office of State Accountants is outlined in Presidential Regulation Number 9 of Year 1961 on the instruction to the Chief of the Office of State Accountants. Meanwhile, the function of monitoring was carried out by the Treasury-General. Later, in 1966, because of the rapid development of government organizations and to increase efficiency and effectiveness as well as to adjust with current developments, an institution was then formed to take over the duties and authority of the Office of State Accountants and the Treasury-General, which was the Directorate-General of State Finance Monitoring (DJPKN) (BPKP 2017).

17 years after the formation of the Directorate-General of State Finance Monitoring, in 1983, for reasons of even rapid development, monitoring also needed to be increased. In addition, the scope of examination became broader, not only for the central and regional governments, but also overseas. Because of this, it was considered necessary to create an institution that could oversee finances and development as well as replace the DirectorateGeneral of State Finance Monitoring. Thus, on 30 May 1983, the Directorate-General of State Finance Monitoring was transformed into the Finance and Development Supervision Body with Presidential Decree Number 31 of Year 1983.

The Finance and Development Supervision Body is a Non-Department Government Agency (LPND) which is subordinate to and directly responsible toward the President, as regulated by law (Keputusan Presiden No 103 Tahun 2001). However, in performing its duties, the Finance and Development Supervision Body is coordinated by the Minister for the Supervision of State Apparatus, now called Minister for the Supervision of State Apparatus and Bureaucratic Reforms, as regulated by a Presidential Regulation (Peraturan Presiden No 64 Tahun 2005).

The Finance and Development Supervision Body in performing its duties is guided by Government Regulation Number 60 of Year 2008 on the Government Internal Control System. As an internal monitoring institution, the Finance and Development Supervision Body does not fully conduct audit approaches or take actions that are repressive in nature but prioritizes preventive approaches instead. If the state incurs losses due to illegal acts that are committed by state institutions, the Finance and Development Supervision Body may be asked to conduct an investigative audit to aid agents of law enforcement in evaluating state losses. An additional task that may be done by the Finance and Development Supervision Body is monitoring across sectors other monitoring activities that are determined by the Minister of Finance or by appointment of the President (PP No 60 Tahun 2008).

The appointment of the President to the Finance and Development Supervision Body is outlined in Presidential Instruction Number 9 on December 312014 to establish monitoring in order to increase regional/state revenue and to maintain efficiency and effectiveness of regional/state expenditures. The purpose of this appointment is to increase the quality, transparency, and accountability of the management of national development and execution of state/regional budget and expenditure to accelerate the achievement of prosperity by the people.

The Inspectorate, as an internal monitoring institution, has a hierarchy of responsibilities. In general, the Inspectorate reports directly to the leader of its organizational unit. The Inspectorate-General is the internal monitoring element at the ministry level. The Inspectorate General holds an office in the national capital because the president and ministers also reside in the national capital. The Inspectorate General reports directly to the minister as the institutional leader.

The Regional Inspectorate is the internal monitoring element at the provincial government level. The Regional Inspectorate is located in the province capital and reports 
directly to the governor, while the Inspectorate of Regencies and Municipalities are internal monitoring elements in at the regency and municipality government levels, and reports directly to the regent or mayor as the leader at the regency or municipal level.

Before the formation of the Inspectorate in 1966, monitoring and audit was known by the abbreviation "wasrik" (monitoring and audit). At the time, wasrik was still very much influenced by Dutch colonial ways of the Inspecteur, and this term was retained in Indonesian as Inspektur (Inspector). This term was then used very broadly in all aspects of governance concerned with controlling duties, including the Chief Inspectorate with the term included.

The Inspectorate has difficult duties since it becomes the first line in the monitoring of financial management. As such, the Inspectorate must have officials that are highly qualified in financial capabilities. In addition to highly skilled human resources, primary tasks and functions also need to be affirmed within a set of legal regulations. In response to this need, the Presidium of the Ampera Cabinet issued Decree Number 15/U/Kep/8/1966 on August 31, 1966, which affirmed the position, primary tasks, and functions of the Department Inspectorate-General. Yet at the time this decree was issued, not all departments in government had an Inspectorate. In present times, all government institutions now have possessed an internal audit institution, of which one is the Inspectorate.

Along with rapid development, the need for monitoring becomes even more pertinent not only in the central government, but also in regional governments, whether provincial, regency, or municipal governments. The dynamics of regional monitoring and its changes are affected by the system of national governance. As such, the government made changes to the fundamentals of regional governance, which is regulated in Law Number 5 of Year 1974. Later, the government issued Law Number 22 of Year 1999 on regional governance in response to the reformation movement, which was then followed by changes in Law Number 32 of Year 2004 on Regional Governance due to the dynamics of regional development. This was then revised with the issuance of Law Number 23 of Year 2014; less than a year later, the government made changes again to the law of regional governance by issuing Law Number 9 of Year 2015.

Monitoring of regional governance in the New Order era was based on the Minister of Home Affairs Decree Number 220 of Year 1979 on the Structure and Methodology of Regional Inspectorates in Regencies and Cities. The dynamics of governance, which grew even more complex, led the government to issue Government Regulation No. 60 of Year 2008 on the Government Internal Controlling System, which regulates the work mechanisms of government internal monitoring apparatuses.

\section{METHODS OF RESEARCH}

This study used a qualitative research methodology utilizing literature study approach. This method was chosen to reveal the phenomenon of supervision that occurs in all state financial supervisors related to the rampant corruption in the government. In addition, it strengthen the researchers' belief that the topics discussed are relevant and appropriate to be studied, therefore it aids in finding the direction of research (Streubert and Cerpenter, 2011). Furthermore, the researchers studied the phenomenon of supervision in greater depth to clarify the role of supervisory institutions in overcoming the state finances corruptions. Various documents, literature and other sources aided researchers to uncover state financial supervision.

The object of this research is the state financial supervisor, namely the House of Representatives, the Regional Representative Council, the Regional House of Representatives, the Audit Board of Indonesia, Finance and Development Supervisory Agency, and the Inspectorate. The research primary sources were obtained from documents and references relating to the implementation of supervision. Additional documents and references were obtained from various sources to support the primary source. In addition, the researcher also conducted interviews with informants competent with the research topic. The informants were chosen as representatives of the state financial supervisory institutions. 
There were 2 to 3 people chosen in each institution, bringing the total informants to 15 people. For the type of data needed were primary data and secondary data. The primary data were interviews with informants and in-depth observations of the supervisory activities carried out by the supervisory institution. Secondary data was obtained from various documents and references such as books, researches, studies, magazines, articles, scientific journals, archives, including various documents and references obtained through the internet.

Data analysis was carried out during observation by making field notes. The researcher observes data collection and tried to understand monitoring activities. Data obtained from observations were then described to portray real conditions. Description of observations, results of interviews, field notes were compared with various documents and references to find the common thread of problems. Based on the data collected, the researcher made a narrative that described the role of the supervisory institution in carrying out its duties and functions as well as the obstacles it faced. The final stage of this data analysis was drawing conclusions and recommendations.

\section{RESULTS AND DISCUSSION}

The "tangled threads" present among the finance monitoring institutions of House of Representatives, Regional Representative Council, Regional House of Representatives, Audit Board of Indonesia, Finance and Development Supervision Body, and the Inspectorate have made these institutions unable to function to their maximum extent due to various issues. The following is an explanation of the "tangled threads" occurring among the monitoring institutions.

The "Tangled Threads" of the House of Representatives, Regional Representative Council, and the Regional House of Representatives. The monitoring conducted by the House of Representatives and Regional House of Representatives is not a technical monitoring, unlike that conducted by the Audit Board of Indonesia, Finance and Development Supervision Body, or the Inspectorate. Instead, the monitoring functions conducted by the House of Representatives and Regional House of Representatives are in the form of hearings, work visits, special committees, interpellations, inquiries, declaration of opinions, and accepting or rejecting proposed laws by the government or proposed regional regulations (PP No 25 Tahun 2004). Meanwhile, the Regional Representative Council conducts monitoring that is in general related to regional interests, for example in regard to breaking up or joining regions, regional autonomy, natural resources, and other matters that concern regional interests (Undang-Undang No 17 Tahun 2014).

Monitoring by the House of Representatives, Regional Representative Council, and the Regional House of Representatives cannot be conducted to the fullest because of the limited abilities of the human resources - the members of the House of Representatives, Regional Representative Council, and the Regional House of Representatives. Some elected members of the House of Representatives, Regional Representative Council, and Regional House of Representatives are not sufficiently skilled to perform their tasks as representatives of the people. As stated by (Marbun, 1994), control and monitoring conducted by members of the legislative is not perfectly executed or only partially done because of the lack of basic as well as technical knowledge that most legislative members have on average, compared to the executive.

Further, (Marbun, 1994) adds that as is often the case in hearings, members of the legislative quickly feel satisfied after executive explanations because of the factor of laziness and lack of personal responsibility as representatives of the people. Even in the 1999 legislative elections, a portion of the newly elected legislative members were only educated up to middle school, and some did not graduate from elementary school.

The same issue is explained by (Husen, 2005); the DPR does not provide enough legal and political support to the findings of the Finance Auditor Body because the House of Representatives members lacks the capacity to quickly understand the Finance Auditor Body results. One of the factors is the educational background of House of Representatives 
members, which are not quite high, especially in the field of finance. In addition, to evaluate a financial report, there is not yet a standard measurement that can be used by members of Republic of Indonesia House of Representatives to be able to judge government responsibility on state finance as explained in Finance Auditor Body reports. Similarly, (Soesatro, Triaswati, Alisjahbana, and Adiningsih, 2005) explain that with regard to monitoring, there is an imbalance between what the House of Representatives knows and what the government knows. The government usually has more mastery and understanding of data than the members of the House of Representatives do. There is also the factor of politics: sometimes some House of Representatives members show understanding of the issues at hand, but do not possess the mettle to address them.

\section{The "Tangled Threads" of the Audit Board of Indonesia}

The Finance Auditor Body is the sole agency for state financial monitoring, possessing authority granted by the 1945 Constitution, Article 23 E, Paragraph 1. Finance Auditor Body must have the authority to freely and independently conduct financial monitoring. No party may intervene in this regard. As such, to guarantee that the audits conducted by the Finance Auditor Body are up to the standards, the government issued Law Number 15 of Year 2004 on the Audit of Management and Responsibility of State Finances. Yet in its practice, the BPK is not free from intrigues of politics and power. This can be seen during the election of Finance Auditor Body leaders, a certain group of Finance Auditor Body leaders are chosen from members of political parties.

These Finance Auditor Body leaders who come from political parties are prone to political intervention from their parties, especially if they are the current ruling parties. Governors, regents, mayors, ministers, and even a president from the same political party as Corruption Eradication Commission leaders may be able to create special relationships. This makes the Finance Auditor Body unable to be free and independent. This is proven in several regions where the regent or mayor is of the same political affiliation as the leaders of the Audit Board of Indonesia; the evaluation for the audit report of the Finance Auditor Body for that region is "Qualified" (Reasonable without Exception). Once the regent or mayor changes to a different political affiliation from the Finance Auditor Body leaders, the evaluation of the Audit Report by the Audit Board of Indonesia for the region is no longer "Qualified". This indicates that a special relationship exists.

Aside from the issue of special relationships, the follow-up of the audit conducted by the Finance Auditor Body does not get support both as politic or as a law enforcement effort, particularly findings by the Audit Board of Indonesia that are related to the embezzlement of state funds (Husen, 2005). One case that appeared in 2016-2017 is the suspected corruption by the Governor of the Special Capital Region of Jakarta, Basuki Tjahaya Purnama (also known as Ahok), in the cases of reclamation of the Bay of Jakarta, Sumber Waras, land purchase in Cengkareng, and others, which the Corruption Eradication Commission declares as not having malicious intent and no indications of corruption. However, results of audit by the Finance Auditor Body state that there were state losses and violations of law in the cases concerned (M. Batubara, 2017). This proves the lack of support from law enforcement officials. For the first time in the history of this republic, an audit report from the Audit Board of Indonesia is not trusted by law enforcement officials.

Another issue that the Finance Auditor Body currently faces is that because the system of government accountability is not yet orderly and comprehensive, the Finance Auditor Body must fend for itself. This may lead the Finance Auditor Body to be caught up in problems and issues that are not fundamental (Soesatro dkk., 2005). Furthermore, some auditors from the Audit Board of Indonesia have been involved in taking bribes for Audit Board of Indonesia evaluations.

The latest case of bribes taken for Audit Board of Indonesia evaluation involves the sting operation by Corruption Eradication Commission on the primary auditor of Audit Board of Indonesia and the Inspectorate-General of the Ministry of Village on 26 May 2017, on the "Qualified" evaluation for the financial audit of the Ministry of Villages, Development of Disadvantaged Regions, and Transmigration (Kuwado, 2017). This case leads to the questioning of the freedom and independence of the Audit Board of Indonesia. Have the 
Audit Board of Indonesia evaluations issued before this case resulted from the practice of taking bribes for evaluation? Thus, Audit Board of Indonesia evaluations issued after this case comes to light will raise doubts among the people.

The Dark Side of the Finance and Development Supervision Body. Finance and Development Supervision Body is the internal monitoring institution that is directly responsible to the president and has the task of monitoring and overseeing the management of governance in general. Structurally, however, it is still on the same level as the Directorate-General under the coordination of the Coordinating Minister for the Monitoring of Development and Supervision of State Apparatus in 1999. As such, the Finance and Development Supervision Body could not yet be said to be independent, since it is still dependent on another institution. In addition, the institution is directly and indirectly influenced by the policies set by the Minister for the Supervision of State Apparatus and Bureaucratic Reforms.

Because of the position of the Finance and Development Supervision Body, which is not at the department level but only equivalent to Echelon I officials of a department, this allows departments examined by the Finance and Development Supervision Body not to give a positive response to the recommendations in the results of audits by the Finance and Development Supervision Body. With such a condition, the Finance and Development Supervision Body cannot be expected to give objective and independent results. In addition, from a budgetary perspective, routine funding for the operations of the Finance and Development Supervision Body is provided by the state secretariat. This also adds to the non-independence of the Finance and Development Supervision Body (Hadin, 2013).

Government Regulation Number 60 of Year 2008 on the government internal control system gives hope for the strengthening of the Finance and Development Supervision Body as a government internal monitoring institution. The Finance and Development Supervision Body becomes an independent institution because it becomes directly responsible to the President. With this, there is equivalence for audits in ministries and non-ministry government institutions, allowing the Finance and Development Supervision Body to carry out its duties in a better and more objective way.

The Finance and Development Supervision Body, aside from being a government internal monitoring institution, is also an external institution for the ministries and non-ministry government institutions that it examines. This causes the institution to have similar duties and functions as the Audit Board of Indonesia, which is indeed also an external audit institution that is independent and free from power influence. The difference is that the Finance Auditor Body gives the report of its examinations to legislative institutions, while the Finance and Development Supervision Body gives its reports to the president. As stated by (Fahrojih, 2016), the changes to the Laws on State Finances have not been able to get rid of issues of overlapping examinations between the Finance and Development Supervision Body and the Audit Board of Indonesia.

The Finance and Development Supervision Body as an external audit institution for ministries and non-ministry government institutions becomes inefficient in its position because the duties of the Finance and Development Supervision Body are also done by the Audit Board of Indonesia, and there is also internal monitoring done by the Inspectorate. Moreover, after the reformation and with the spirit of regional autonomy, the government issued Law Number 22 of Year 1999 on Regional Governance. The dynamics of regional development led to changes to the governance laws as in Law Number 23 of Year 2014. Yet further changes were made as Law Number 9 of Year 2015 on regional governance. This law on regional governance has delegated some authority to the regional governments, among them fiscal decentralization and reduction of monitoring functions from the central government. This condition is dilemmatic for the Finance and Development Supervision Body, because on one hand the Finance and Development Supervision Body performs external monitoring on the government institutions it examines, but on the other it performs internal monitoring on government and development activities.

To increase state revenue, the president commanded the Finance and Development Supervision Body to conduct audits on state revenue sectors as well as other sectors related 
to state revenue. This presidential order is stated in Presidential Instruction Number 9 of Year 2014. However, this instruction causes overlap between the Finance and Development Supervision Body and the Inspectorate. The reality is that for all levels there exists an Inspectorate, which for the central level is the Inspectorate-General, for the provincial level is the Regional Inspectorate, and for regencies or cities their respective Inspectorates.

The existence of the Finance and Development Supervision Body and the Inspectorate as internal monitoring agencies also creates an overlap in conducting duties of field auditing with the Audit Board of Indonesia. As mandated by Law Number 15 of Year 2004 which concerns financial audits, the Audit Board of Indonesia may conduct post-audits or preaudits. This means the Audit Board of Indonesia has authority not only to examine state finance responsibilities but also to examine the management of state finances, which should be noted that this is the authority of internal monitoring apparatus, which in this case is the Finance and Development Supervision Body or the Inspectorate.

The "Tangled Threads" of the Inspectorate. The Inspectorate as the internal monitoring institution for regional governments in examining finances has not been fully freed from institutional association with regional chiefs, which in this case are regents, mayors, or governors, because it is indeed the duty of the Inspectorate for internal monitoring of their governments. The effect of this status is that the Inspectorate cannot perform its functions to the fullest as a monitoring institution.

The organizational structure of regional Inspectorates that makes them subordinate to regional chiefs, whether regents, mayors, or governors, or even ministers creates doubt as to whether the Inspectorates are in fact independent for the institutions concerned. As explained by (Pickett, 2010, hlm. 340), as long as an internal audit organization is situated within an organizational unit, then it is not independent. Similarly, Alex Marwata, the Deputy Chief of the Corruption Eradication Commission (Putro, 2017) explains that regional Inspectorates have not been fully independent because they may be influenced by regional chiefs that can appoint monitoring officials however they wish, and this makes the Inspectorates unable to maximally perform. As a result, regional governance does not proceed optimally.

Minister of Home Affairs Tjahjo Kumolo suggested that the authority for the appointment and termination of regional Inspectorates and regional functional officials be given to the central government to avoid conflicts of interest whether in the form of arrogant regional chiefs, political clashes, or kinship conflicts that cause the Inspectorate to not become independent (Mihardja, 2017). (Bastian, 2003) explains that there are three obstacles that the auditor faces in duty: personal obstacles that result from the self of the auditor, external difficulties that manifest outside the self, and organizational obstacles that result from the place of work. (Cahyat, 2004) explains that current government responsibilities prioritize more on accountability than substantial matters.

Independence is also regulated in a minister regulation (Permen PAN RI, 2008) on the Code of Ethics of Government Internal Monitoring Apparatus, where in Part D that regards principles of behavior and the sub-part of objectivity, it is stated that an auditor must be professionally independent in regard to collecting evidence, performing evaluation, and processing data or information. In addition, an auditor must also pay attention in performing an evaluation of a situation, including its relevance. Independence of an auditor is needed in making decisions without being influenced by any other party. (Arens and Loebbecke, 1997) explain that independence means the auditor is not biased in performing audit tests, evaluating results, and issuing audit reports, while (Jones and Pendlebury, 2000) explain that the independence that applies to internal audits is to ensure that the internal control system on public services that the organization provides runs economically, efficiently, and effectively.

The appointment of officials including inspectors might possibly be done because of the factor of familiarity with a regent, mayor, governor, or minister and this phenomenon can be clearly seen after a regional chief has been elected. A newly elected regional chief will almost assuredly reassign and transfer many people in the regional government environment due to urging from their campaign committee. People who are considered to have significant 
contribution toward the election of a certain regional chief will usually obtain a certain "strategic" position as a reward.

Such a condition, if it happens in the Inspectorate, would undermine the inspectorate's independence, and this is a common phenomenon that occurs in almost every regency and city in Indonesia. Azwar Abubakar, a former Minister for the Supervision of State Apparatus and Bureaucratic Reforms (Angga, 2015) had also stated that internal monitoring institutions must be independent. Internal monitoring for the government should not be of the same instance as the institution being monitoring, such as in the case of the regency Inspectorate being appointed by the regent. "This is what makes the Inspectorate as an internal supervisory institution appear awkward and not independent in its examinations."

The Inspectorate is sometimes an "exile" for officials that are opposed to the regional chief or a "parking location" before moving into a better position; these conditions make the Inspectorate an institution that lacks professionalism because its positions are filled by people who have not been prepared to conduct the functions of the Inspectorate as a credible internal monitoring institution. This argument is supported by Syamsul Hilal (D. Batubara, 2012) who states that the 140 billion IDR misspending case in North Sumatera shows that the Inspectorate is not professional in its monitoring function and task. Hilal explains further that had the Inspectorate been at their best, resilient, and professional, budget misspending would have been greatly minimized, but because its performance was poor, the end result was as such.

\section{CONCLUSION}

Monitoring of state finance is an inevitability that must continue to be performed to keep state finance from misspending. Various monitoring institutions such as the House of Representatives, Regional Representative Council, Regional House of Representatives, Audit Board of Indonesia, Finance and Development Supervision Body and Inspectorate carry out the monitoring function. However, the results have not been optimum as we can see from the level of misspending that is still high.

Monitoring by members of the House of Representatives, Regional Representative Council, and Regional House of Representatives hindered by the lack of skills and knowledge of the House of Representatives, Regional Representative Council, and Regional House of Representatives members on financial monitoring considering that there is no requirement of mastery of state finances to be a House of Representatives, Regional Representative Council, or Regional House of Representatives member. Additionally, House of Representatives, Regional Representative Council, and Regional House of Representatives members sometimes quickly feel satisfied about explanations from the executive.

The Finance Auditor Body as an external monitoring institution has not been able to carry out its functions to the fullest. Currently, the Audit Board of Indonesia is more focused on conducting post-audits to evaluate the feasibility of government financial reports. Meanwhile, the budgeting process also becomes the part which is prone to corrupt practices, and the Finance Auditor Body has not been able to investigate this. Moreover, the Audit Board of Indonesia also has many internal problems such as the selection of Finance Auditor Body members, which is politically motivated, and the practice of taking bribes for Finance Auditor Body audit results.

The Finance and Development Supervision Body is structurally present under the president, so in carrying out its duties, the Finance and Development Supervision Body function as an external monitoring institution for ministries and non-ministry institutions. This makes the tasks of Finance and Development Supervision Body inefficient because the tasks of the Finance and Development Supervision Body can be performed by the Audit Board of Indonesia and there is also the Inspectorate that do the tasks internally. The same is true of the Inspectorate, which as an internal monitoring institution has not been able to carry out this duty maximally and independently because it has ties with regional chiefs, who have the authority to appoint and terminate Inspectors. 


\section{REFERENCES}

1. Andrianto, J., \& Irianto, G. (2008). Akuntansi and Kekuasaan: Bank BUMN Indonesia. Malang: FEB UB bekerjasama Aditya Media Publishing.

2. Angga, D. (2015). Pengawasan Internal Pemerintah Belum Maksimal Koran Sindo. Retrieved from https://nasional.sindonews.com/read/973867/149/pengawasan-internalpemerintah-belum-maksimal-1425869281

3. Arens, A. A., \& Loebbecke, J. K. (1997). Auditing, an Integrated Approach. USA: Prentice-Hall Internasonal, Inc.

4. Asosiasi Auditor Intern Pemerintah Indonesia (AAIPI). (2014). Kode Etik Auditor Intern Pemerintah Indonesia. Jakarta: AAIPI

5. Bastian, I. (2003). Audit Sektor Publik. Jakarta: Visi Global Media

6. Baswir, R. (2000). Akuntansi Pemerintahan Indonesia. Yogyakarta: BPFE.

7. Batubara, D. (2012). Kebocoran Rp170 M Bukti Inspektorat Tidak Profesional. Retrieved from http://www.mandailingonline.com/kebocoran-rp170-m-bukti-inspektorat-tidakprofesional/

8. Batubara, M. (2017). Usut Tuntas Dugaan Korupsi Ahok, Menuntut Keadilan untuk Rakyat. Jakarta: YPSI (Yayasan Pengkajian Sumberdaya Indonesia).

9. BPKP. (2017). Perjalanan BPKP Mengawal Pembangunan Nasional. BPKP Kawal Akuntabilitas and Pembangunan. Jakarta: BPKP

10. Cahyat, A. (2004). Sistem Pengawasan Terhadap Penyelenggaraan Pemerintah Daerah Kabupaten Governance Brief. Bogor: CIFOR Center for Internasional Forestry Research.

11. Direktorat Jenderal Anggaran. (2015). Pedoman Proses Perencanaan, Penganggaran, and Pelaksanaan APBN. Jakarta: Kementeran Keuangan.

12. Duska, R., Duska, B. S., \& Ragat, J. A. (2011). Accounting Ethics. USA: Wiley-Blackwell.

13. Fahrojih, I. (2016). Pengawasan Keuangan Negara. Malang: Intrans Publishing.

14. Goddard, A., Assad, M., Issa, S., Malagila, J., \& (2016). The two publics and institutional theory-A study of public sector accounting in Tanzania. Critical Perspectives on Accounting, 40, 8-25.

15. Hadin, A. F. (2013). Eksistensi Badan Pengawasan Keuangan and Pembangunan di Era Otonomi Daerah. Yogyakarta: Genta Press.

16. Handajani, L. (2010). Menggagas Akuntansi Publik Terintegrasi” pada Sektor Publik. Jurnal Akuntansi Multiparadigma (JAMAL), 1(1), 121-140.

17. Husen, L. O. (2005). Hubungan Fungsi Pengawasan, Dewan Perwakilan Rakyat Denngan Badan Pemeriksa Keuangan Dalam Sistem Ketatanegaraan Indonesia. Bandung: Utomo.

18. Instruksi Presiden Nomor 1. (1989). Instruksi Presiden Republik Indonesia tentang Pedoman Pelaksanaan Pengawasan Melekat.

19. Jones, R., \& Pendlebury, M. (2000). Public Sector Accounting ( $5^{\text {th }}$ Ed.). London: Prentice Hall.

20. Keputusan Presiden No 103 Tahun 2001. Kedudukan, Tugas, Fungsi, Kewenangan, Susunan Organisasi, and Tata Kerja Lembaga Pemerintah Non Departemen.

21. Kumorotomo, W. (2014). Filosofi Pengawasan: Peran Lembaga Pengawas and Pemeriksa Daerah, Materi Pelatihan Pengawasan Keuangan Daerah.

22. Kuwado, F. J. (2017). Jadi Tersangka OTT KPK, Pejabat and Auditor BPK dibebastugaskan, Kompas.

23. Liu, J., \& Jin, B. (2012). Government Auditing and Corruption Control: Evidence from China's Provincial Panel Data. China Journal of Accounting Research, 5, 163-186.

24. Lowensohn, S., Johnson, L. E., Elder, R. J., \& Davies, S. P. (2007). Auditor Specialization, Perceived Audit Quality, and Audit Fees in the Local Government Audit Market. Journal of Accounting and Public Policy, 26, 705 - 732.

25. Ludigdo, U. (2007). Paradoks Etika Akuntan. Yogyakarta: Pustaka Pelajar.

26. Manan, B. (2005). DPR, DPD, and MPR dalam UUD 1945 Baru. Yogyakarta: FH-UII Press. 
27. Marbun, B. N. (1994). DPRD, Pertumbuhan, Masalah and Masa Depannya. Jakarta: Erlangga.

28. Maroun, W., \& Atkins, J. (2014). Section 45 of the Auditing Profession Act: Blowing the Whistle for Audit Quality? The British accounting review, 46, 248-263.

29. Mihardja, T. (2017). Perkuat Inspektorat Daerah. Jakarta: Kompas

30. Peraturan Presiden No 64 Tahun 2005. Perubahan Keenam atas Keputusan Presiden Nomor 103 Tahun 2001 Tentang Kedudukan, Tugas, Fungsi, Kewenangan, Susunan Organisasi, and Tata Kerja Lembaga Pemerintah Non Departemen.

31. Permen PAN RI. 2008. Kode Etik Aparat Pengawasan Intern Pemerintah. PER/04/M.PAN/03/2008.

32. Pickett, K. H. S. (2010). The Internal Auditing Handbook ( $3^{\text {rd }}$ Ed). England: Wiley.

33. PP No 25 Tahun 2004. Pedoman Penyusunan Tata Tertib DPRD. Sistem Pengendalian Intern Pemerintah.

34. Rozi, E. S. (2010). Parlemen Indonesia, Geliat Volksraad Hingga DPD, Menembus Lorong Waktu Doloe, Kini, and Nanti. Bandung: Alfabeta.

35. Sekretariat Utama BPK RI. 1972. 25 Tahun Badan Pemeriksa Republik Indonesia. Jakarta: Sekretariat Utama Badan Pemeriksa Keuangan.

36. Soesatro, H., Triaswati, N., Alisjahbana, A., \& Adiningsih, S. (2005). Pemikiran and Permasalahan Ekonomi di Indonesia dalam Setengah Abad Terakhir. Yogyakarta: ISEI Kerjasama Kanisius.

37. Streubert, H. J., \& Cerpenter, D. R. (2011). Qualitative Research in Nursing: Advancing The Humanistic Imperative. Philadelphia PA: Lippincott: Wolters Kluwer Helth.

38. Sujana, E. (2012). Pengaruh Kompetensi, Motivasi, Kesesuaian Peran and Komitmen Organisasi Terhadap Kinerja Auditor Internal Inspektorat Pemerintah Kabupaten (Studi pada Kantor Inspektorat Kabupaten Badung and Buleleng). Jurnal IImiah Akuntansi and Humanika (JINAH), 2(1), 34-41.

39. Syafruddin, A. (1991). DPRD (Dewan Perwakilan Rakyat Daerah) Sebagai Badan Legislatif Daerah Dari Masa ke Masa. Bandung: Mandar Maju.

40. Tuanakotta, T. M. (2013). Audit Berbasis ISA (Internasional Standards on Auditing). Jakarta: Salemba Empat.

41. Undang-Undang No 17 Tahun 2014. Majelis Permusyaratan Rakyat, Dewan Perwakilan Rakyat, Dewan Perwakilan Daerah, and Dewan Perwakilan Rakyat Daerah.

42. Undang-Undang No 22 tahun 2003. Susunan and Kedudukan MPR, DPR, DPD, DRD.

43. Undang-Undang No 27 tahun 2009. Susunan and Kedudukan MPR, DPR, DPD, DPRD.

44. Wawo, A. B. (2012). Pengaruh Pengawasan Internal and Eksternal, Gaya Kepemimpinan and Implementasi Good Public Governance Terhadap Kinerja Pelaporan Keuangan (Studi pada Satuan Kerja Perangkat Daerah (SKPD) di Provinsi Sulawesi Tenggara) (Unpublished Disertation). Program Doktor Ilmu Manajemen, Program Pascasarjana Fakultas Ekonomi and Bisnis Universitas Brawijaya, Malang.

45. Wibowo, A. (2015). Presiden Kecewa Kinerja Pengawasan Keuangan Masih Buruk. Retrieved from http://www.antaranews.com/berita/495966/presiden-jokowi-nilai-kinerjapengawasan-keuangan-masih-buruk

46. Wiyono, B. S. (2014). Pengawasan, Materi Pelatihan Inspektorat Kota Surakata. Surakarta.

47. Zawilska, A., \& Albury, S. (2015). An Ethnomethodologically-Informed Approach to Interface Design for Social Interactions around Video Online. Paper presented at the ICWSM. 